\title{
7
}

\section{Analysis of the University Student's Satisfaction with the Introduction of New Methods of Teamwork}

\author{
M. Remedios Belando-Montoro \\ mbelando@ucm.es \\ Orcid: 0000-0001-5730-7896 \\ Complutense University of Madrid
}

\author{
M. Aránzazu Carrasco-Temiño \\ mcarrasco@ucm.es \\ Orcid: 0000-0001-5760-8234 \\ Complutense University of Madrid
}

\begin{abstract}
Teamwork is currently one of the most highly demanded competences among university students by companies. In this paper we make a contribution to research into the area through an experience of educational innovation. We assess the level of satisfaction of a student group with the deployment of teamwork through a collaborative software open. To this end, an exploratorydescriptive study has been carried out and a questionnaire has been used with questions on technological skills and satisfaction in ICT knowledge. Among the results, the highest score questions are: the student's ability to coordinate a group activity carried out on the internet, knowledge about information programs in which to share information on the network with peers and the use of cloud storage systems. The advantages detected when using a web application for group work for the first time are related to the motivation and the greater involvement of the students, as well as a better distribution of tasks among the different members of the group and a more effective follow-up of the development of the works by the teacher and coordinator responsible for the group.
\end{abstract}

Keywords: university student's teamwork, technological skills, learning methods, social education 


\subsection{Introduction}

Teamwork is currently one of the most highly demanded competences among university students by companies. There are many researches that we find on this subject, but as stated by Driskell, Salas \& Driskell (2018), despite being in the golden age of publications on this subject, much of the results are preliminary and point to the need for further research.

Therefore, in this paper we make a contribution to research into the area through an experience of educational innovation in which we value the satisfaction of a group of students with the introduction of teamwork through a collaborative software open.

\section{Background}

Europe's higher education system must face in the coming years major challenges linked, among others, through innovation, persistent social divisions and the necessary counter capabilities. As noted in the communication from the European Commission on a renewed EU agenda for higher education,

"All advanced learning students, regardless of subject matter, need to acquire advanced cross-disciplinary skills and key competencies that enable them to succeed: high-level digital skills, writing and calculation, autonomy, critical thinking and the ability to problem solving are increasingly crucial attributes" (European Commission, 2017, p.5).

Among these cross-disciplinary skills, for university students the acquisition of skills related to teamwork is fundamental. These are competences that will serve not only to satisfactorily overcome their university studies but also, in a medium and long term, will be of great use in their future professional performance, as the experience carried out by Lakkala et al. (2017) in which they formed work teams with students of Teaching and Social Work. According to these authors, this type of work combines commitment and efficiency together with tensions and dilemmas.

Also, as it was concluded in the research of Ramírez, Rodríguez \& Blotto $(2016,77)$, "The small group could be a first instance to validate or not a scientific proposal. The act of verbalizing arguments to a partner and receiving explanations from others provides students with the opportunity to rehearse modes of expres- 
sion in scientific terms, free of charge. pressures - real or imaginary - by the presence of the teacher".

The teamwork is, therefore, one of the most effective tools in the classrooms in general and concretely, in the university ones, since it improves the academic performance of the students (Delgado Rivera et al., 2017; Férez \& Cutillas, 2015).

In addition, currently companies identify teamwork as one of the key capabilities for staff recruitment because, as Miller (2003) indicates, organizations base their decisions, develops strategies and measure performance workers through teamwork (Delgado Rivera et al., 2017; Férez \& Cutillas, 2015; Park, Kim, Park, \& Park, 2015).

On the other hand, and specifying in the study presented here, in the degree in which research has been developed (Degree in Social Education), the transversal competence that refers to teamwork has been written as follows:

Value the importance of teamwork and acquire skills to work interdisciplinary within and outside organizations, from planning, design, intervention and evaluation of different programs or any other intervention that may require it.

Interest in this methodology is also present in various degrees from all areas of knowledge in Spanish Universities. The recognition of this relevance in the training of university students has inspired several innovative experiences in the university environment such as Carballo (2013), Coronado (2013); Guitert, Romeu, \& Pérez-Mateo (2007); Leris, Fidalgo, \& Sein-Echaluce (2014); Lozano, Romano, \& Segovia (2014); Messetti, Dusi, \& Rodorigo (2016) and Valiente (2013), among others.

On the other hand, the methodology of group work has some specific characteristics, of which we highlight, following Coronado (2013, p. 174), the following: motivates the students on the subject to be treated, makes the students responsible for their work, encourages the group discourse in the classroom, integrates the group comments, the students learn from their personal and group experience, encourages reflection, exchange and participation. And in the study by Putra and Fibra (2016) it was shown that group work is the main element in the generation of innovation.

These characteristics of group work make it a complex methodology that involves personal factors and interrelation with others 
that, at times, generates problems among the components of the group that can prevent the realization of a good job (Belando \& Carrasco, 2014).

Canto et al. (2009) analyzed the most common conflicts faced by students when they work as a team. These are: imbalance in what each member of the group does, difficulty in reaching an agreement, imbalance in the levels of motivation and ambition of the members, and distrust when it comes to sharing information. However, these authors argue that the presence of conflicts should not lead teachers to give up working with this methodology, rather it should be seen as an advantage since it allows not only the learning of technical knowledge but also cross-disciplinary skills that are very useful in the professional world.

Another of these cross-disciplinary skills is, as was acknowledged in the communication of the European Commission mentioned at the beginning, digital competences. It is a fact that new technologies have transformed both learning processes and the same knowledge and skills, both in the workplace and in the development of leisure activities. In the university area of ICT management is imprescindible for all its members, both students and faculties must have adequate technology management. In the specific case of students, research shows that learning experiences through ICT are valued positively by them (Maquilón, Mirete, García, \& Hernández, 2013; Rubio \& Escofet, 2014).

In addition, the study carried out by Gutiérrez-Porlán, RománGarcía, \& Sánchez-Vera (2018) it detects that university students show greater use of Internet tools for collaborative work. However, in the same study it has been detected that students do not conceive ICT as a learning space. According to this idea, another study indicates that the knowledge that students have of the tools they have at their disposal is still scarce, although students are constantly connected to the network, there are tools that are completely unknown to them and it is detected that the tools that are devote more time to those already know how to use (White \& Le-Cornu, 2011).

This should lead us to reflect on whether methodologies carried out in university classrooms are consistent, or not, with the specific needs of the students. For example, the study carried out by Vilches Vilela \& Reche Urbano (2019) shows that the use of WhatsApp as a group work tool limits the relationships between group participants and communication processes. Therefore, as 
teachers we must improve the vision that students have towards ICT and the network, bringing their perception closer to that of an effective and adequate collaborative learning space.

"Collaborative technological tools can generate new learning scenarios derived from the impact that the evolution of communications has had on the way people work and on the structure of organizations" (Muñoz-Repiso, Martín, \& Payo, 2012, p. 162).

\subsection{Methodology}

Considering the scenario described above mind, it has drawn up an exploratory-descriptive study, where you want to study student satisfaction with the methodology of teamwork, through a technological tool in a subject's degree of Social Education.

In the study we have combined two complementary research methodologies, since two major objectives are proposed with each of the parties. On the one hand, exploratory designs are used in order to prepare the ground for future research and are, generally, the antecedent to any other study. This design is used when the research plan is to examine a field little studied and, therefore, there are many questions unanswered (Hernández, Fernández, \& Baptista, 2014). On the other hand, the descriptive designs, the same authors define them as the investigation that tries to describe situations, contexts or events.

For all the above, this type of study has been selected to obtain an approximation to the satisfaction and technological learning that students have when an innovative element is introduced in the university classroom. In addition, this study may allow the implementation of a larger experiment in the future in which we can have control groups to improve the results and study in depth the effect that the introduction of technologies for group work in the classroom, may have in the development of students. For this, the following objectives are proposed:

- Know the satisfaction with the subject of the students.

- Know the satisfaction with the selected tool for time management.

- Evaluate the degree of knowledge of students after the use of this tool.

- Measure the evolution of learning perceived by students. 
The experience was carried out in the subject "Planning and management of socio-educational programs", where the teaching methodology was adapted to introduce the use of the Trello tool as a means to elaborate group work.

The selection of the tool to use is a fundamental aspect in the study, since it must meet a series of criteria, as evidenced in a previous study (Belando-Montoro \& Carrasco-Temiño, 2014), in which the characteristics of ten applications that facilitate group work were analyzed. It was demonstrated that the use of the selected tool (Trello) was quite simple, free and, although part of its software is in English, it allows to rename both the boards and the lists and tasks, which allows students to adapt it to their needs. To this is added the fact that the way of visualizing the pending tasks is very intuitive and the monitoring by the teacher can be done quite easily. When starting the course/project/work, Trello it acts as if it was a mind map because it allows to put all the ideas on the cards for individual tasks, then sort or prioritize them according to importance or due dates and add attachments (Woods, 2017).

No control has been in the study, only the experimental group. This supposes a limitation for the interpretation of the data, since it can not be indicated that the results are due to the implementation of said tool. However, for the implementation of further studies to develop this methodology, it is you study may provide a basis that offers data and interesting tracks on various issues.

A survey was conducted at the beginning of the course and another at the end, which was completed in the computer room of the Faculty of Education through Google, so that all students had the opportunity to participate in the study.

This study has a great relevance, since it allows us to detect the satisfaction of the students with teaching innovations in the classroom and, therefore, to develop more and more and better methodologies to use in the classroom.

\section{Sample}

The sample consists of students enrolled in the 4th semester of Grade in Social Education at the Complutense University of Madrid of tomorrow's group. In the pre-test, 42 subjects participated and in the post-test the sample was reduced to 29 students. This mortality of the sample is the cause of the evolution of the 
students in the subject, since the post-test was applied at the end of the semester and in these last days the students begin to be absent from the classes for the preparation of exams and/or endof-course assignments.

\section{Instrument}

The instrument used for this study is a self-made questionnaire, both in the pre-test and in the post-test. A series of demographic questions were asked about the availability of ICT for students and other questions structured in three blocks:

- Technological competences of students

- Previous ideas about program development

- Satisfaction in the knowledge of ICT

The measured items are presented on a scale of 1 to 4 , where 1 means "nothing true" and 4 "very true". For the posttest, questions about the availability of ICT for students technological skills of students and more general questions related to the skills associated with the subject remained were removed. In addition, in the section of previous ideas about the preparation of programs, items related to the subject to be taught were kept and questions about satisfaction with the class taught were added. Finally, in the section on satisfaction with ICT knowledge, a large part of the questions is eliminated, adding three on satisfaction with the teamwork tool and time management used.

\section{Process}

The data obtained were grouped, tabulated and analyzed with the statistical package SPSS, where all the results presented below were elaborated. On the one hand, a descriptive statistic was carried out and, on the other hand, pre-experimental statistics with a pretest-posttest design with a group. The statistical tests used were the T-Student for related samples and the Wilcoxon test based on the homogeneity of variances between the different variables. 


\subsection{Results}

Regarding the results of the study, the first thing that was analyzed was the familiarity that students have with new technologies, so that we could guarantee the continuity of experience in their home, since they had enough knowledge to perform this experience. $95 \%$ of the students of the subject indicate that they have a computer at home and $90 \%$ indicate having internet at home. However, regarding the use of computer class in the faculty, almost $74 \%$ of them say they do not use it. These data are consistent it each other and we can see that students have technological support at home that permit them properly and follow the class from their homes and have no need to use the computer classroom of the faculty.

It was also necessary to discover the technological competences of the student that they had at the beginning of the semester to adapt the training in the selected ICT tool, as well as in other adjacent resources that might be needed for an adequate use of the subject.

To do this several questions about skills and competencies related to the management of computers that are detailed in the Graphic 1. In this, as it can be seen by the responses provided by students, they have a high knowledge of management information systems in general. This level can be classified as a user level, since the resolution of problems in the computer does not obtain a score as high as the rest, which indicates a lack of more advanced knowledge. It should also be noted that also get a low score paragraph consulting them on the use of leaves $c$ to calculation, confirming knowledge to indicate user level.

Finally, the item is staked referred to knowledge of collaborative work programs, where the average score does not reach the value of 2 . This indicates that students have a generic knowledge about the use of new technologies, but do not know specialized programs that can support them in their work professional as collaborative work tools could be. 
Basic knowledge of a computer and its peripherals.

Knowledge of a computer and its most common peripherals: printers, scanners, ...

Solve problems such as configuring email, configuring antivirus, defragmenting the hard drive.

You are able to install and uninstall computer programs

You can change the file formats (convert a file from one type to another).

You know s make a document written with a word processor, using advanced techniques of the same

You can design, create and modify spreadsheets, using their functions such as formatting cells, inserting and hiding rows, performing dynamic tables, ...

You know how to create a multimedia presentation, including static images, texts, audio clip, video clip, graphics.

You know how to use collaborative work software.

Graphic 1. Technological skills of students.

\section{Pretest-Postest comparisons in student technological competencies}

For the pretest-postest analysis of the results obtained, it is necessary to verify the normality of variances in the sample previously, using the Kolmogorov-Smirnov and Shapiro-Wilk tests. This test has indicated a significance of less than 0.05 in all items included in the questionnaire, so the sample does not follow a normal distribution.

Based on this result, it is determined to perform the contrast of the differences between the pretest and the posttest through the non-parametric Wilcoxon test in all the comparative variables. In this test it has indicated a significance less than 0.05 in all the items included in the questionnaire, so the sample does not follow a normal distribution.

With respect to the ranges of the variables, it must be indicated that in the variables analyzed in pretest and posttest, better values are detected in the posttest. Although the absence of a control 
group, we can not state that this improvement is due to the application of the methodology, but a set of factors influencing the student. Next, the variables analyzed and the results in each of them are detailed.

In the item, "You are able to coordinate a group activity carried out on the internet" we found 19 positive and 2 negative ranges and according to the $\mathrm{Z}$ statistic and its associated $\mathrm{p}$, we can affirm that there are statistically significant differences in the pre-test and post-test measurements and the number of positive ranges indicate that the scores are higher in the post-test. Specifically, the average of this item in the pre-test is 2.49 and in the post-test a value of 3.28 is obtained. Therefore, in the post-test students perceive greater ability to coordinate team activities with their peers that can be done through the internet.

\begin{tabular}{|c|c|c|c|c|}
\hline Ran & & & & \\
\hline & & $\mathbf{N}$ & $\begin{array}{c}\text { Average } \\
\text { Range }\end{array}$ & $\begin{array}{l}\text { Sum of } \\
\text { ranges }\end{array}$ \\
\hline $\begin{array}{l}\text { You are able to coordinate a group activity carried out } \\
\text { on the Internet, for example in an electronic forum. } \\
\text { PRETEST-You are able to coordinate a group activity }\end{array}$ & $\begin{array}{l}\text { Negative } \\
\text { ranges }\end{array}$ & $19 \mathrm{a}$ & 11,42 & 217,00 \\
\hline carried out on the Internet, for example in an electronic & Posive ranges & $2 b$ & 7,00 & 14,00 \\
\hline & Ties & $7 \mathrm{c}$ & & \\
\hline & Total & 28 & & \\
\hline a. PRETEST $<$ POSTEST & & & & \\
\hline b. PRETEST $>$ POSTEST & & & & \\
\hline c. PRETEST $=$ POSTEST & & & & \\
\hline
\end{tabular}

Test statisticsa

\begin{tabular}{|c|c|}
\hline & $\begin{array}{c}\text { You are able to coordinate a group activity carried out on the } \\
\text { Internet, for example in an electronic forum. PRETEST-You are able } \\
\text { to coordinate a group activity carried out on the Internet, for } \\
\text { example in an electronic forum. POSTEST }\end{array}$ \\
\hline$Z$ & $-3,645 b$ \\
\hline $\begin{array}{r}\text { asymptotic significance } \\
\text { (bilateral) }\end{array}$ & .000 \\
\hline $\begin{array}{l}a . \quad \text { rank test of Wilcoxon } \\
b . \quad \text { It is based on positive range. }\end{array}$ & \\
\hline
\end{tabular}

Figure 1. Wilcoxon 1 test 
It was also investigated in the knowledge that the students had before and after the subject, on computer programs in which they could share information on the network with the rest of their classmates. In this case, 15 positive and 3 negative ranks were obtained, as shown in Figure 2, and we can confirm through the $Z$ statistic, that students obtain higher scores in the question after the subject. In the initial questionnaire, an average of 3.12 was obtained and after the subject rose to 3.55, therefore, at the end of the subject they affirmed have knowledge about computer programs with which they can share information on a network with their peers.

\begin{tabular}{|c|c|c|c|c|}
\hline & & $\mathbf{N}$ & $\begin{array}{c}\text { Average } \\
\text { Range }\end{array}$ & $\begin{array}{c}\text { Sum of } \\
\text { ranges }\end{array}$ \\
\hline \multirow{4}{*}{$\begin{array}{l}\text { You know computer programs to share information on } \\
\text { the network with your colleagues PRETEST - You know } \\
\text { computer programs to share information on the network } \\
\text { with your colleagues POSTTEST }\end{array}$} & $\begin{array}{l}\text { Negative } \\
\text { ranges }\end{array}$ & $15 \mathrm{a}$ & 9,80 & 147,00 \\
\hline & Posive ranges & $3 b$ & 8,00 & 24,00 \\
\hline & Ties & $10 \mathrm{c}$ & & \\
\hline & Total & 28 & & \\
\hline \multicolumn{5}{|l|}{ a. PRETEST < POSTEST } \\
\hline \multicolumn{5}{|l|}{ b. PRETEST $>$ POSTEST } \\
\hline c. $\quad$ PRETEST $=$ POSTEST & & & & \\
\hline
\end{tabular}

Test statisticsa

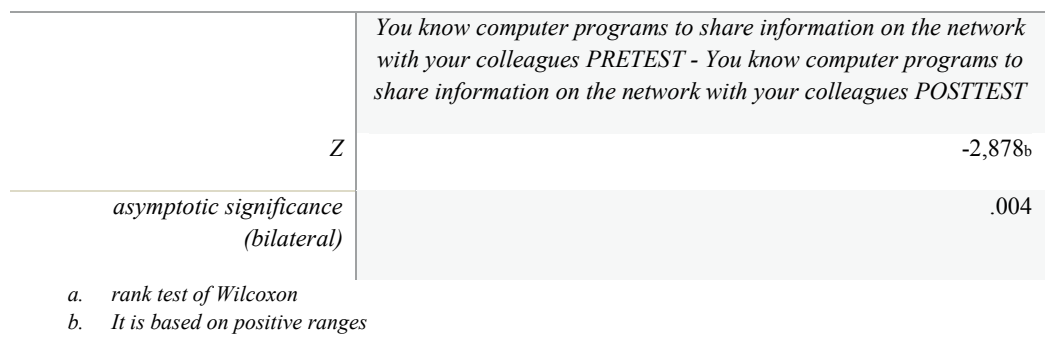

Figure 2. Wilcoxon 2 test

It was also examined if the students make use of the existing cloud storage systems, since for the development of the subject they required to have an account in these types of system together with their peers. In this case, 20 negative and 2 positive ranges were obtained, which, together with the significance of the lower alpha sta- 
tistic, indicates that there were better results in the post-test questionnaire. The mean in this case also shows an important increase, since it goes from 2.05 in the pre-test to 3.21 in the post-test.

\begin{tabular}{|c|c|c|c|c|}
\hline & & $\mathbf{N}$ & $\begin{array}{l}\text { Average } \\
\text { Range }\end{array}$ & $\begin{array}{l}\text { Sum of } \\
\text { ranges }\end{array}$ \\
\hline \multirow{4}{*}{$\begin{array}{l}\text { Easily use cloud storage systems PRETEST - Easily } \\
\text { use cloud storage systems POSTTEST }\end{array}$} & $\begin{array}{l}\text { Negative } \\
\text { ranges }\end{array}$ & $20 \mathrm{a}$ & 12.05 & 241,00 \\
\hline & Posive ranges & $2 b$ & 6,00 & 12,00 \\
\hline & Ties & $5 c$ & & \\
\hline & Total & 27 & & \\
\hline \multicolumn{5}{|l|}{ a. $\quad$ PRETEST $<$ POSTEST } \\
\hline \multicolumn{5}{|l|}{ b. PRETEST $>$ POSTEST } \\
\hline c. $\quad$ PRETEST $=$ POSTEST & & & & \\
\hline
\end{tabular}

Test statisticsa

\begin{tabular}{|c|c|}
\hline \multirow[b]{2}{*}{$Z$} & $\begin{array}{c}\text { Easily use cloud storage systems PRETEST - Easily use cloud } \\
\text { storage systems POSTTEST }\end{array}$ \\
\hline & $-3,787 b$ \\
\hline $\begin{array}{r}\text { asymptotic significance } \\
\text { (bilateral) }\end{array}$ & .000 \\
\hline $\begin{array}{l}\text { a. rank test of Wilcoxon } \\
b . \quad \text { It is based on positive rang }\end{array}$ & \\
\hline
\end{tabular}

Figure 3. Wilcoxon 3 test

To conclude the analysis of the results, in the section on technological skills of students, they were asked about the knowledge about conducting consultations in national and international databases. The statistic of both items is significant, indicating the positive and negative ranges of these, which improved the results after the subject, since their means are higher in the post-test, as can be seen in the following table.

Table 1. Media knowledge databases

\begin{tabular}{lcc}
\hline & Pretest & Postest \\
\hline You know how to consult in national databases & 1.78 & 2.66 \\
\hline You know how to make queries in international databases & 1.68 & 2.34 \\
\hline
\end{tabular}




\section{Satisfaction with the subject}

In general, one of the objectives of the study and the project was to know the satisfaction of students with the subject, so that it can be determined whether the improvement in satisfaction is solely due to the tool used or, on the contrary, if it is due to the subject as a whole.

In this case, a good degree of student satisfaction is detected, highlighting the response received to the item: "The deliveries through the virtual market have been adequate", which is very close to 4, which is the maximum possible score (see Figure 2). The rest of the items are located in values very close to 3 of the scale, which is a positive assessment, highlighting slightly among them the item related to the knowledge acquired in the class to make an adequate evaluation of the program and / or project carried out. In addition, deviations from the data show a grouping of results, which describes homogeneity of responses among students. You can see the means in Graphic 2.

\begin{tabular}{l}
$\begin{array}{l}\text { You have acquired knowledge to carry out an } \\
\text { adequate evaluation of the program and/or } \\
\text { project carried out. } \\
\text { The contents seen in class have been adequate } \\
\text { With what you have seen in class, you have } \\
\text { improved the ICT knowledge for your } \\
\text { professional work. } \\
\text { The use of the Moodle platform in the subject } \\
\text { has been adequate } \\
\text { You have improved your ICT knowledge with } \\
\text { the subject } \\
\text { Deliveries through the virtual campus have } \\
\text { been adequate }\end{array}$ \\
\hline
\end{tabular}

Graphic 2. Average rating of the sample on different statements regarding satisfaction with the subject 


\section{Satisfaction with the selected tool}

To analyze the satisfaction that students have with the implementation of a tool like Trello in the subject, they were included in the post-test three questions as you relate with it. Next, the descriptive results that show the satisfaction of the students are detailed with the selected tool.

The first was the adequacy of the explanation of the tool to be used, since this tells us if the kind of initiation to the program that was carried out in the first days of class on the tool has been adequate (see table 2). The average is at 3.48 , which is a high value considering that the measurement of the variable was of intervals with values between 1 and 4 . In addition, the median reaffirms that the explanation was perceived by students as very adequate

On the other hand, they were asked if the use of Trello had allowed them to better organize the subject. On this occasion, the average stands at 2.62, which indicates that there is good satisfaction in this regard.

Table 2. Trello. Explanation and relationship with the organization of the subject

\begin{tabular}{lccc}
\hline & $\begin{array}{c}\text { The management of } \\
\text { Trello has allowed you } \\
\text { to better organize the } \\
\text { subject }\end{array}$ & $\begin{array}{c}\text { The explanation } \\
\text { of Trello has been } \\
\text { adequate }\end{array}$ & 29 \\
\hline Valid & 29 & 13 \\
\hline Lost & 13 & 3.48 \\
\hline Half & 2.62 & 4.00 \\
\hline Median & 3.00 & 738 \\
\hline Standard deviation &, 942 & 730 \\
\hline
\end{tabular}

Next, it was examined whether they considered the introduction of Trello in the subject adequate (see table 3). On this occasion, the question gave the option of yes or no, so we are going to analyze it through the percentage of both items. Students indicated that they considered adequate the introduction of Trello in the subject account for almost $83 \%$ of the sample, so we can say that the class generally agrees with the application of a task manager in subject of the way it was done. 
Table 3. Pertinence of Trello in the subject

\begin{tabular}{llcccc}
\hline \multicolumn{5}{c}{ You consider adequate the introduction of Trello in the subject } \\
\hline \multirow{2}{*}{ Valid } & Frequency & Percentage & $\begin{array}{c}\text { Valid } \\
\text { percentage }\end{array}$ & $\begin{array}{c}\text { Accumulated } \\
\text { percentage }\end{array}$ \\
\cline { 2 - 6 } & YES & 24 & 82,76 & 82,76 & 82,76 \\
\cline { 2 - 5 } & DO NOT & 5 & 17,24 & 17,24 & 100.0 \\
\hline
\end{tabular}

\section{Perceived evolution}

Finally, he tried to know the evolution that the students themselves perceived of their knowledge and skills after the subject. These issues allow us to be aware of the improvement students perceive about their basic computer knowledge and theoretical knowledge about socio-educational programs and projects. In addition, we wanted to know the improvement in collaborative work software skills concretely. For this, these questions were interspersed throughout the questionnaire. The results are shown in the following graphic:

You have improved your basic knowledge about how a computer works

You have improved your theoretical knowledge about socioeducational programs and projects

You have improved your skills in collaborative work software

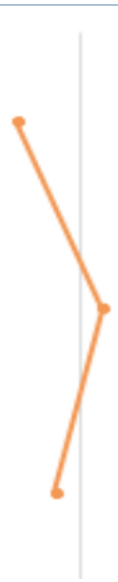

Graphic 3. Average rating of the sample on different claims related to the evolution perceived by students in knowledge and skills 
The highest average score is awarded to theoretical knowledge about socio-educational programs and projects, which is to be expected, since it is one of the main objectives of this specific subject. The knowledge and skills related to the collaborative learning experience through Trello obtain lower scores, but achieve the approved, since they exceed 2.5. The improvement of basic computer skills was not an objective with this experience, however, they were also questioned about it and students perceive how their knowledge has improved, since they have been forced to intensify the use of these devices for the completion of the tasks of the subject, therefore, in this item they obtain a score of 2.59. As it regards the perception of the class about their skills in software for collaborative work, here a value of 2.83 is obtained, which indicates that students perceive that they were improving their skills.

Therefore, we can conclude this section of analysis of results indicating that the students of the subject have at the beginning of it a knowledge at user level of technology in general and highlights the low score of the item referred to the knowledge of collaborative work programs. With respect to the technological competence perceived by the student before and after, we find that all the variables obtain significant differences between both measurements. Specifically, they obtain the highest score in the post-test, the question referred to the student's ability to coordinate a group activity carried out on the internet, knowledge about information programs in which to share information on the network with peers and the use of computer systems, cloud storage. Regarding the satisfaction of these students, with respect to the subject in general, the scores of all the items are close to 3 , with a Likert scale of 1 to 4 , positively highlighting the satisfaction with the deliveries made by the virtual campus. Now we specify the satisfaction of the selected tool and this is also positive, although not as intense as with the subject in general. Finally, the evolution of the students themselves perceive $n$ after the experience is very positive, because the values of these items are located and $n$ good place. 


\subsection{Conclusions}

One of the objectives of using applications such as Trello for group work was to avoid one of the problems that arise when using this methodology, and that not all the components of the group work equally. In this way, the teacher can check the work done by each student, the internal organization of the work, and the dates of delivery of each of the tasks within the group. In addition, with this way of working, it is possible to naturalize the follow-up of group work and maintain high the level of demand of all group members during all the months the subject lasts. Moreover, and coinciding with what was demonstrated in a previous study (Carrasco-Temiño, Belando-Montoro, \& García-Garzón, 2017), it can be said that this tool improves the competence of time management in students.

The positive results found on the use of Trello in the teaching of higher education coincide with the experiences of Delgado, Mesquida, \& Mas (2014) focused on the follow-up of the apprehension of work teams and that of Maněna, Maněnová, Myška, \& Rybenská (2015) which defends that Trello is the best tool to help students to plan their tasks well and guide them in their obligations. Also, in the studio of the Prtljaga, Nedimović, \& Đorđev (2016) hold the valuable role of the use of Trello in the organization and planning of work in higher education institutions. In our case, most of the class considers the introduction of such a tool adequate, which confirms the results obtained by the mentioned authors.

In particular, our students, after passing through the subject, are more able to coordinate group activities carried out through the Internet, they know more computer programs to share information on the network with their colleagues and they use cloud storage systems more easily. Although it is true that, as we have indicated previously, we can not confirm a direct relationship between the data and the tool due to the lack of a control group. Although after the good results obtained, the realization of the same experience with the measurement of a control group is not ruled out.

In addition, data on student satisfaction indicate that the introduction of these innovations in the classroom is a strategy well accepted by students. Therefore, although Trello has been 
selected to be used in the work of the subject " Planning and management of socio-educational programs", as has been reported in previous pages, it is an application that can be useful for group work of any kind. subject as well as in any work environment, so the results of this research can serve as a basis for other research that aims to deepen the use of ICT tools for group work in the university field.

The advantages detected when using a web application for group work for the first time are related to the motivation and the greater involvement of the students, as well as a better distribution of tasks among the different members of the group and a more effective follow-up of the development of the works by the teacher and coordinator responsible for the group.

\section{References}

Belando-Montoro, M. R. \& Carrasco-Temiño, M. A. (2014). Una experiencia de aplicación de TIC para facilitar el trabajo en grupo en ámbitos socioeducativos. In Alonso, D. \& Valiente, M. (coords.), V Encuentro Internacional de intercambio de experiencias innovadoras en la docencia. Madrid: Universidad Complutense de Madrid y Universidad Politécnica de Madrid, pp. 69-75.

Del Canto, P., Gallego, I., López, J. M., Mora, J., Reyes, A., Rodríguez, E., Sanjeevan, K., Santamaría, E., \& Valero, M. (2009). Conflictos en el trabajo en grupo: cuatro casos habituales. Revista de Formación e Innovación Educativa Universitaria, 2 (4), 211-226.

Carballo, R. (2013). Aprender haciendo en grupo: experiencia innovadora. In Carballo, R. (dir.), Aprendiendo e innovando desde la experiencia. Madrid: Universidad Complutense de Madrid, pp 181-196.

Carrasco-Temiño, M.A., Belando-Montoro, M. R., \& García-Garzón, E. (2017). Improving students time management skills using web platforms: a critical review and educative applications. In López-Meneses, E., Sirignano, F. M., Reyes-Tejedor, M., Cunzio, M. L. \& GómezGalán, J. (ed.), European innovations in education: research models and teaching applications. Afoe: Sevilla, pp. 187-199.

Comisión Europea (2017). Comunicación de la Comisión al Parlamento Europeo, al Consejo, al Comité Económico y Social Europeo y al Comité de las Regiones sobre una agenda renovada de la UE para la educación superior. COM, 247 final. 
Coronado, M. G. (2013). Metodología de trabajo en grupo y desarrollo de espacios de aprendizaje e integración. In Carballo, R. (dir.), Aprendiendo e innovando desde la experiencia. Madrid: Universidad Complutense de Madrid, pp. 171-176.

Delgado, A., Mesquida, A. L., \& Mas, A. (2014). Utilización de Trello para realizar el seguimiento del aprendizaje de equipos de trabajo, Actas del Simposio/Taller XX JENUI. Oviedo: Universidad de Oviedo, pp. 53-58.

Delgado Rivera, M., Fasce Henry, E., Pérez Villalobos, C., Rivera Fuentes, N., Salazar Saéz, P., Riquelme Vallejos, C., \& Campos Cerda, I., (2017). Trabajo en equipo y rendimiento académico en un curso de kinesología empleando aprendizaje basado en equipos. Investigación en Educación Médica, 6 (22), 80-87.

Driskell, J. E., Salas, E., \& Driskell, T. (2018). Foundations of teamwork and collaboration. American Psychologist, 73 (4), 334-348. Available at $<$ http://dx.doi.org.bucm.idm.oclc.org/10.1037/amp0000241>.

Férez, P. C. \& Cutillas, P. M. (2015). Trabajo en equipo frente a trabajo individual: ventajas del aprendizaje cooperativo en el aula de traducción. Tonos Digital, 28, 1-21. Available at <https://dialnet.unirioja.es/ servlet/articulo?codigo $=4952439>$.

Guitert, M., Romeu, T., \& Pérez-Mateo, M. (2007). Competencias TIC y trabajo en equipo en entornos virtuales, Revista de Universidad $y$ Sociedad del Conocimiento, 4 (1). Available at <http://www.uoc.edu/ rusc/4/1/dt/esp/guitert_romeu_perez-mateo.pdf>.

Gutiérrez-Porlán, I., Román-García, M., \& Sánchez-Vera, M. (2018). Estrategias para la comunicación y el trabajo colaborativo en red de los estudiantes universitarios, Comunicar, 26 (54), 91-100. Available at <http://dx.doi.org/10.3916/C54-2018-09>.

Hernández, R., Fernández, C., \& Baptista, P. (2014). Metodología de la investigación. México: McGrall-Hill.

Lakkala, S., Turunen, T. A., Kangas, H., Pulju, M., Kuukasjärvi, U., \& Autti, H. (2017). Learning inter-professional teamwork during university studies: a case study of student-teachers' and social work students' shared professional experiences, Journal of Education for Teaching, 43 (4), 414-426.

Leris, D., Fidalgo, A., \& Sein-Echaluce, M. L. (2014). A comprehensive training model of the teamwork competence, International Journal of Learning and Intellectual Capital, 11 (1), 1-19.

Lozano, M., Romano, I., \& Segovia, M. M. (2014). Efectos del trabajo en grupo en el rendimiento académico y en el grado de satisfacción del alumnado. Comunicación al I Seminario Iberoamericano de Innovación 
Docente de la Universidad Pablo de Olavide, 20-21 de noviembre de 2014. Available at <http://riemann.upo.es/congresos/index.php/sididoupo/ sidiupo/schedConf/presentations>.

Maněna, V., Maněnová, M., Myška, K., \& Rybenská, K. (2015). Comparative study of online tools in preparation for future teachers for use in cooperative learning methods. In Chan, K. (ed.), Future Communication Technology and Engineering. London: Taylor and Francis Group, pp. 65-68.

Maquilón, J. J., Mirete, A. B., García, F. A., \& Hernández, F. (2013). Valoración de las TIC por los estudiantes universitarios y su relación con los enfoques de aprendizaje, Revista de Investigación Educativa, 31 (2), 537-554.

Miller, D L (2003). The Stages of Group Development: A Retrospective Study of Dynamic Team Processes. Canadian Journal of Administrative Sciences / Revue Canadienne des Sciences de l'Administration, 20 (2), 121134. Available at <https://doi.org/10.1111/j.1936-4490.2003.tb00698.x>.

Messetti, G., Dusi, P., \& Rodorigo, M. (2016). Convertirse en grupo de trabajo: Un modelo de didáctica universitaria, Revista Interuniversitaria de Formación del Profesorado, 86 (30.2), 147-160.

Muñoz-Repiso, A. G., Martín, A. H., \& Payo, A. R. (2012). La metodología a metodología del aprendizaje colaborativo a través de las TIC: Una aproximación a las opiniones de profesores y alumnos/Methodology of collaborative learning through ICT: An approach to the professors and students opinions. Revista Complutense de Educación, 23 (1), 161-188.

Park, H.-R., Kim, C.-J., Park, J.-W., \& Park, E. (2015). Effects of teambased learning on perceived teamwork and academic performance in a health assessment subject, Collegian, 22 (3), 299-305. Available at <https://doi.org/10.1016/j.colegn.2014.05.001>.

Prtljaga, P., Nedimović, T., \& Đorđev, I. (2016). Improving organization and skills of planning in higher education using new informational communicative technology. In Barković, D. \& Runzheimer, B. Interdisciplinary Management Research XII. Opatija: Josip Juraj Strossmayer University of Osije, pp. 303-312.

Putra, S. \& Fibra, A. (2016). Teamwork as an Innovation Generator: An Analysis of Project Hatchery at Binus University International. Pertanika Journal Social Sciences \& Humanities, 24 (S), 139-154.

Ramírez, S., Rodríguez, J., \& Blotto, B. (2016). El equipo de trabajo como estrategia de aprendizaje, InterCambios: Dilemas y Transiciones de la Educación Superior, 3 (1), 70-79. 
Rubio, M. J. \& Escofet, A. (2014). Visiones de los estudiantes de la docencia universitaria mediada por TIC, Pixel-Bit: Revista de Medios $y$ Educación, 45, 217-230.

Valiente, M. (2013). Proyectos de innovación educativa en la Universidad. Innovaciones docentes, nuevas tecnologías, trabajo en equipo, educación en la Universidad. In Carballo, R. (dir.), Aprendiendo e innovando desde la experiencia. Madrid: Universidad Complutense de Madrid, pp. 215-222.

Vilches Vilela, M. J. \& Reche Urbano, E. (2019). Limitaciones de WhatsApp para la realización de actividades colaborativas en la universidad, RIED. Revista Iberoamericana de Educación a Distancia, 22 (2), 57-77. Available at <https://doi.org/10.5944/ried.22.2.23741>.

White, D. \& Le-Cornu, A. (2011). Visitors and residents: A new typology for online Engagement. First Monday, 16 (9). Available at <http://doi. org/10.5210/fm.v16i9.3171>.

Woods, D. (2017). Trello, The School Librarian, 65 (3), 147. Available at <http://0-search.proquest.com.cisne.sim.ucm.es/docview/ 1939915638 ? accountid $=14514>$. 
